\title{
HLA-DMA wt Allele
}

National Cancer Institute

\section{Source}

National Cancer Institute. HLA-DMA wt Allele. NCI Thesaurus. Code C150072.

Human HLA-DMA wild-type allele is located in the vicinity of 6 p21.32 and is approximately $20 \mathrm{~kb}$ in length. This allele, which encodes HLA class II histocompatibility antigen, DM alpha chain protein, is involved in the post-translational modification of class II major histocompatibility protein complexes. 